\title{
A Comprehensive Review: Natural Polymers Used for Fast Dissolving Mouth Film
}

\author{
Shivani B. Sontakke Patil*1, Dr. Shubhangi Daswadkar ${ }^{2}$ \\ 1. Department of Quality Assurance, Dr. D. Y. Patil College of Pharmacy, Akurdi, Pune, Maharashtra, India 411044. \\ 2. Associate Professor, Department of Chemistry, Dr. D.Y. Patil College of Pharmacy, Akurdi, Pune, Maharashtra, India 411044.
}

*Corresponding author's E-mail: sontakkeshivani49@gmail.com

Received: 18-09-2020; Revised: 14-11-2020; Accepted: 23-11-2020; Published on: 15-12-2020. ABSTRACT

Current innovations have introduced suitable measurement choices from the oral course for pediatrics, geriatric, abnormal, nauseous or turbulent patients. Fast dissolving mouth Film is formulated utilizing hydrophilic polymers that quickly disintegrate on the tongue or buccal pit, conveying the medication to the systemic circulation through disintegration when contact with the fluid is made. Hydrophilic polymers are utilized as film formers for quick dissolving films. The water-soluble polymers accomplish quick dissolution, great mouth feel, and mechanical properties to the films. Quick dissolving oral thin film offers quick, exact dosing in a safe, effectual format that is advantageous and convenient, without the requirement for water or estimating gadgets. These days, because of numerous issues related to drug release and side effects producers are slanted towards utilizing natural polymers. In this review article, various polymers are utilized for the formulation of fast dissolving mouth film like Pullulan, Gelatin, Sodium Alginate, Pectin, Rosin, Starch, Chitosan are discussed together about their physicochemical properties and film shaping properties.

Keywords: Natural polymers, Plasticizers, Fast dissolving mouth film, fast dissolving thin film, oral mouth film.

QUICK RESPONSE CODE $\rightarrow$

DOI:

10.47583/ijpsrr.2020.v65i02.003

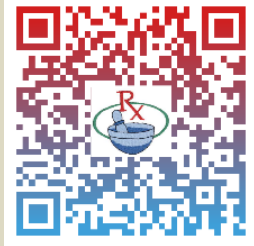

DOI link: http://dx.doi.org/10.47583/ijpsrr.2020.v65i02.003

\section{INTRODUCTION}

$\mathrm{T}$

he oral course is the most secure and attractive course for the administration of therapeutic agents for the utilization of human just as the veterinary. ${ }^{1,2}$ Thin films are certainly not an on- going detailing rather, they had been at first acquainted in late 1970 with beat gulping challenges as found in tablets and capsules. A few different names of these oral films have been shown up; for instance, oro-dispersible films (ODFs), oral soluble films, mucoadhesive films, oral strips, oral thin films, buccal films, wafers, ophthalmic films, and transmucosal films. It is an ultrathin strip (50-150 microns thick) of postage stamp size with a functioning specialist and different excipients created based on transdermal patch technology. ${ }^{3,4}$ Oral Dissolving Films are quick breaking down thin films having a zone going from 5 to $20 \mathrm{~cm}^{2}$ in which active pharmaceutical ingredient (API) is solidified as a matrix using hydrophilic polymer. The active pharmaceutical ingredients are frequently merged up to $15 \mathrm{mg}$ related to different excipients i.e., plasticizers, sugars, taste modifiers, colorants, and so forth. Prescriptions stacked in buccal adhesive films are assimilated legitimately through a buccal tissue layer that passes on it to the foundational flow to show its impact. ${ }^{5}$
As the fast-dissolving strip uses a sublingual course, fast ingestion of medication is conceivable; this at long last prompts the quick beginning of medication activity. New and novel oral drug delivery framework disintegrates or scatters rapidly in a couple of seconds after placing in the mouth without drinking and biting. ${ }^{6}$ It at that point quickly breaks down surprisingly fast and disintegrates to discharge medication for oro-mucosal assimilation. ${ }^{7}$ Dissolvable oral thin film or oral strip has developed in recent years from confection and oral care advertises as breath strips and become a novel and broadly acknowledged structure by shoppers for conveying nutrients and individual care items. ${ }^{8}$ Buccal film favours the delivery of medications having a threat of wastage through first pass impact, having low permeability, enzymatic debasement, and can be influenced by the variable condition of the gastrointestinal tracts. ${ }^{9}$

Medications with poor bioavailability just as with shorter half-life can be managed without any problem. Buccal films can discharge the topical medications with continued and controlled impacts and profitable over the customary drug delivery systems that are utilized in the current of different diseases. The oral film fuses various components for its itemizing which joins polymers, dynamic pharmaceutical fixing, film offsetting administrators, sugars, flavours, colours, salivation strengthening experts, added substances, surfactants, etc. yet the first and far most an amazingly fundamental fixing which helps in film advancement is a Polymer. Assortments of polymers are accessible for the readiness of fast dissolving mouth films. The utilization of film framing polymers in oral films has pulled in impressive consideration in clinical and nutraceutical applications. The determination of polymer 
is one of the most significant and basic parameters for the effective improvement of the film formation. The polymers can be utilized alone or in the blend to acquire the ideal film properties. Oral fast-dissolving film is generally another dose structure in which thin film is readied utilizing hydrophilic polymers, which quickly disintegrates on the tongue or buccal cavity. ${ }^{10}$ As the strip framing polymer (which shapes the stage for the FDF) is the most basic and significant part of the FDF at any rate $45 \% \mathrm{w} / \mathrm{w}$ of polymer ought to, for the most part, be available dependent on a complete load of the dry film however regularly 60 to $65 \% \mathrm{w} / \mathrm{w}$ of polymer is wanted to get wanted properties. ${ }^{11}$

The polymers employed in the oral film preparation should be-- Non-Toxic and Non-Irritant, devoid of leachable impurities, not retard disintegration time of the film, tasteless, should have good wetting and spreadability property, should exhibit sufficient peel, shear and tensile strength, readily available, inexpensive, should have sufficient shelf life, should not aid in causing secondary infections in the oral mucosa or dental regions. ${ }^{12}$

Hydrophilic polymers can be biocompatible and have hence pulled in broad consideration in biomedical and drug delivery applications. They can be tailor-structured at both the molecular level and the gadget level. Significant applications in the biomedical field have been found by Hydrophilic polymers. ${ }^{13}$

Now a day, both natural and synthetic polymers are utilized for the preparation of fast mouth dissolving film.

Classification of polymers used for Mouth dissolving film is as shown in Table 1.

Table 1: Polymer Available for Preparation of $\mathrm{MDF}^{1,7,8,11}$

\begin{tabular}{|l|l|l|}
\hline S.No. & Polymer & Examples \\
\hline 1. & $\begin{array}{l}\text { Natural } \\
\text { Polymers }\end{array}$ & $\begin{array}{l}\text { Pullulan, Starch, Gelatin, Pectin, } \\
\text { Sodium alginate, Maltodextrins, } \\
\text { Polymerized Rosin }\end{array}$ \\
\hline 2. & $\begin{array}{l}\text { Synthetic } \\
\text { Polymers }\end{array}$ & $\begin{array}{l}\text { Hydroxypropyl methylcellulose, } \\
\text { Sodium Carboxy methyl cellulose, } \\
\text { Polyethylene oxide, Hydroxypropyl } \\
\text { cellulose, Polyvinyl pyrrolidone, } \\
\text { Polyvinyl alcohol }\end{array}$ \\
\hline
\end{tabular}

Both synthetic and natural polymers are accessible yet the utilization of normal polymers for pharmaceutical applications is appealing because they are efficient, promptly accessible, and non-dangerous. They are fit for medical modifications, conceivably biodegradable, and with hardly any special cases, likewise biocompatible. ${ }^{14,15}$ Biopolymers are also used in the controlled release delivery systems. Substances of plant starting point represent a few potential difficulties, for example, being combined in little amounts and in blends that are perplexing, which may vary as per the area of the plants just as different factors, for example, the season. This may bring about a moderate and costly detachment and sanitization process. Error! Reference source not found., 17 Another issue that has become progressively significant is that of intellectual property rights.

\section{Importance of Herbal Polymers over Synthetic Polymers is- ${ }^{18}$}

They are biodegradable, biocompatible and non-toxic, economic, safe and devoid of side effects and also easily available.

Therefore, due to these above superiorities of natural polymers over synthetic polymers, the natural polymers are now preferred instead of the synthetic ones.

\section{Classification of Natural Polymers: ${ }^{18}$}

Classification of natural polymers is as shown in Figure 1.

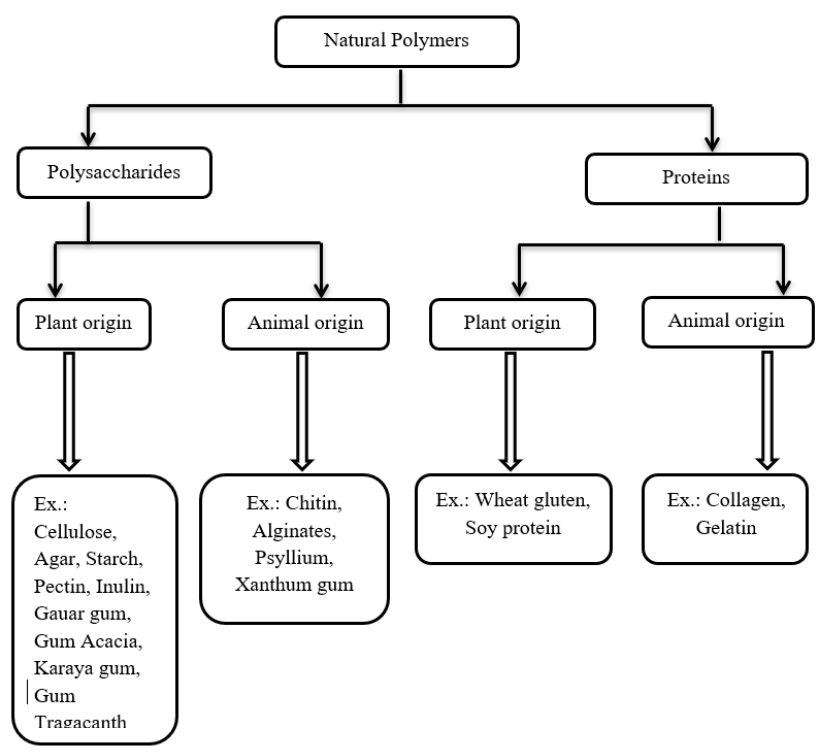

Figure 1: Classification of Natural polymers ${ }^{18}$

This review aims to study the natural polymers used for fast mouth dissolving films, and this is performed by studying the research and review work done of the last 10 years.

Different polymers are utilized for the preparation of fast dissolving oral film. Some of them are discussed beneath together with their physicochemical properties and film forming capacities.

\section{Pullulan:}

The fundamental structure is a straight $\alpha$-glucan one, produced using three glucose units connected $\alpha-(1,4)$ in maltotriose units which are connected in $\alpha-(1,6)$ way. The three glucose units in maltotriose are associated with $\alpha-(1$, 4) glycosidic bond, though back to back maltotriose units are associated with one another by $\alpha-(1,6)$ glycosidic bond. The standard rotation of $(1 \rightarrow 4)$ and $(1 \rightarrow 6)$ bonds brings about two unmistakable properties of auxiliary adaptability and upgraded dissolvability. The one of a kind linkage design likewise enriches pullulan with distinctive physical attributes alongside adhesive properties and its ability to form fibers, compression moldings, and strong, 
oxygen impermeable films. The $\alpha-(1,6)$ linkages that interconnect the rehashed maltotriose units along the chain are liable for the flexible adaptation. ${ }^{19}$ Chemical structure and some quality parameters are as shown in Figure 2 and Table 2.

\section{Gelatin:}

Gelatin is set up by the thermal denaturation of collagen, detached from animal skin, bones, and fish skins. ${ }^{18}$ Gelatin is a conventional term for a blend of filtered protein divisions acquired either by partial acid hydrolysis (type $A$ gelatin) or by partial alkaline hydrolysis (type $B$ gelatin) of animal collagen and additionally may likewise be a blend of both. The protein parts consist for the most of amino acids consolidated by amide linkages to form linear polymers. ${ }^{12}$

Mammalian gelatins ordinarily have better physical properties and thermo stability than most fish and this has been connected for the most part to their higher amino acid substance. There is the utilization of mammalian gelatin in the elaboration of palatable film or coating. ${ }^{20}$ Chemical structure and some quality parameters are as shown in Figure 2 and Table 2.

\section{Sodium Alginate:}

Alginate is an indigestible biomaterial. Primarily sodium alginate comprises sodium salt of alginic corrosive, which is a blend of polychronic acids made out of deposits of Dmannuronic acid and L-guluronic acid. ${ }^{21}$

Palatable films made from alginate structure solid films and show poor water resistance because of their hydrophilic nature. A blend of starch and alginate to form edible film improves the mechanical properties of the film. Chemical structure and some quality parameters are as shown in Figure 2 and Table 2.

\section{Pectin:}

Pectin is a heterogeneous gathering of acidic polysaccharides. This complex anionic polysaccharide is made out of $\beta$-1,4linked d-galacturonic acid residues, wherein the uronic acid carboxyl are either completely (HMP, high methoxy gelatin) or in part (LMP, low methoxy gelatin) methyl esterified. ${ }^{12,} 14$

With Chitosan, HMP or LMP forms magnificent films. To be sure, the cationic nature of chitosan offers the likelihood to exploit the electrostatic interactions with anionic polyelectrolytes, for example, pectin. ${ }^{7}$ Chemical structure and some quality parameters are as shown in Figure 2 and Table 2.

\section{Rosin:}

Rosin is a thermoplastic acidic item. It is a hydrophobic and biodegradable biomaterial. It is principally a resin acid. Rosin is otherwise called colophony or colophonia resina from its native in Colophon, an old lonic city. ${ }^{1,14}$

Films prepared from the plasticizer-free solutions were smooth and transparent yet brittle. The addition of plasticizers plays an important role in the presentation of film coating, which brings about diminished tensile strength, decreased $\mathrm{Tg}$, and expanded elongation and flexibility of the films. ${ }^{7,12}$ Chemical structure and some quality parameters are as shown in Figure 2 and Table 2.

\section{Starch:}

Biopolymer starch is made out of glucose units and having two fundamental constituents are amylose and amylopectin. ${ }^{22}$ The starch got from various sources has a varying quantity of amylose and amylopectin normally 16 $28 \%$ of amylose content in starch granules, though waxy starch exclusively contained amylopectin. Starch observed in nature in three principle crystalline allomorphs assigned as $A, B$, and V-type. B-type crystalline is quickly formed by amylose rich starch films and gradually by the aging of amylopectin rich starch films. Amylose is liable for the filmforming ability of starch. ${ }^{7}$

Starch mostly or completely replace plastic polymer. The films are see-through or translucent, flavorless, tasteless, and colorless.

Films of high-amylose corn starch or potato starch were progressively stable during aging, lost little of their elongation, and had not or a slight expansion in tensile strength.

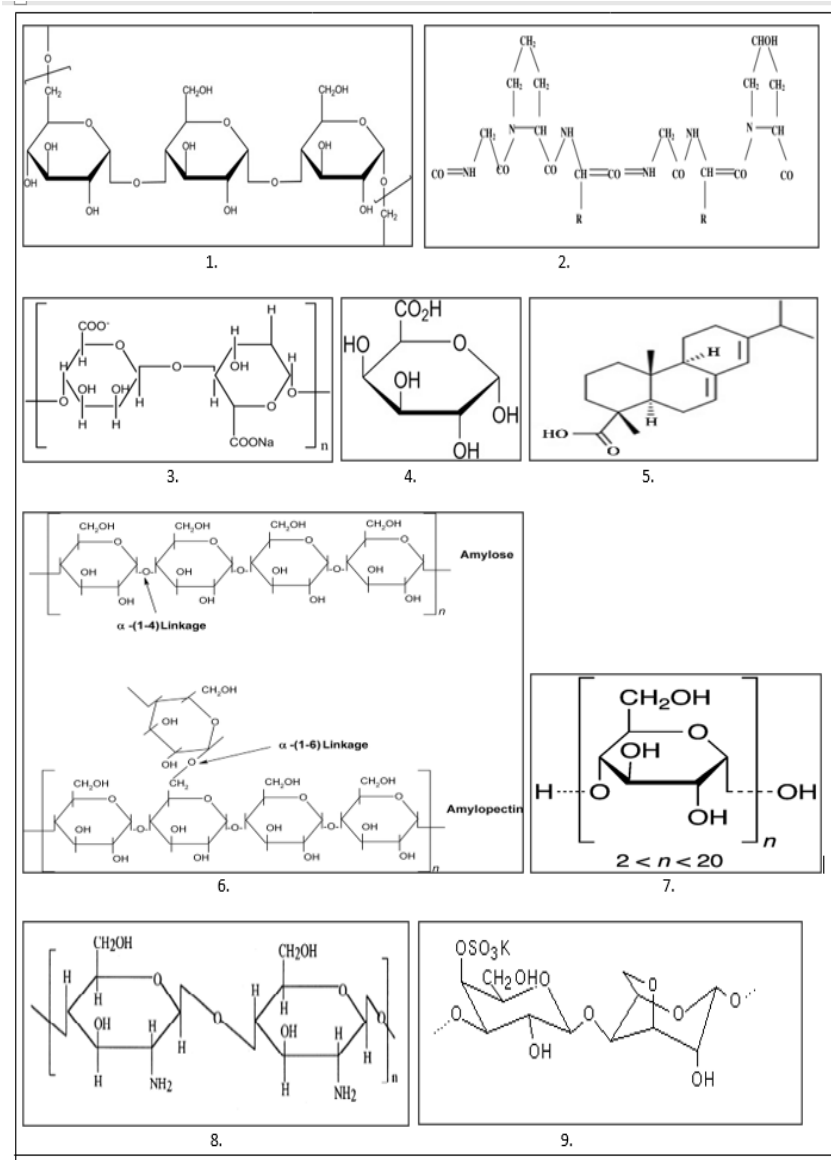

Figure 2: Chemical structures of some different natural polymers.

1.Pullulan. 2.Gelatin. 3.Sodium alginate. 4.Pectin. 5.Rosin. 6.Starch. 7.Maltodextrin. 8.Chitosan. 9.Gum carrageenan 
Table 2: Some quality parameters of some different natural polymers 7,8

\begin{tabular}{|c|c|c|c|c|c|c|c|c|c|}
\hline \multirow{2}{*}{$\begin{array}{l}\text { S. } \\
\text { No }\end{array}$} & \multirow[t]{2}{*}{ Polymer } & \multicolumn{5}{|c|}{ Quality parameters } & \multirow[t]{2}{*}{ Solubility } & \multirow[t]{2}{*}{ Properties } & \multirow[t]{2}{*}{ Reference } \\
\hline & & Appearance & $\begin{array}{l}\text { Water } \\
\text { solubility } \\
\left(25^{\circ} \mathrm{C}\right)\end{array}$ & $\mathrm{pH}$ & $\begin{array}{c}\text { Moisture } \\
\text { (\% loss on } \\
\text { drying) }\end{array}$ & $\begin{array}{l}\text { Molecular } \\
\text { weight } \\
\text { (kDa) }\end{array}$ & & & \\
\hline 1. & Pullulan & $\begin{array}{l}\text { White or } \\
\text { yellowish-white } \\
\text { powder. }\end{array}$ & $\begin{array}{l}\text { It's easily } \\
\text { soluble. }\end{array}$ & $5-7$ & $\begin{array}{l}\text { Maximum } \\
6\end{array}$ & $100-250$ & Water soluble & $\begin{array}{l}\text { Neutral, non-toxic, non-immunogenic, biodegradable, non- } \\
\text { mutagenic, non-carcinogenic, impermeable to oxygen, high adhesion } \\
\text { and film forming abilities, non-ionic polysaccharide and is blood } \\
\text { compatible. It is flexible and spinnable, being a good adhesive and } \\
\text { binder. Pullulan can be made into films of high elasticity and which } \\
\text { are oil and grease resistant. }\end{array}$ & $\begin{array}{c}7,8,9 \\
12,24 \\
25\end{array}$ \\
\hline 2. & $\begin{array}{l}\text { Sodium } \\
\text { Alginate }\end{array}$ & $\begin{array}{l}\text { White to pale } \\
\text { yellowish- } \\
\text { brown colored } \\
\text { powder. }\end{array}$ & $\begin{array}{l}\text { It's slowly } \\
\text { soluble in } \\
\text { water, } \\
\text { forming a } \\
\text { viscous } \\
\text { colloidal } \\
\text { solution. }\end{array}$ & 7.2 & $\begin{array}{l}\text { Maximum } \\
15\end{array}$ & 1828 & $\begin{array}{l}\text { Practically insoluble in ethanol } \\
\text { and ether, also insoluble in other } \\
\text { organic solvents and acid. }\end{array}$ & $\begin{array}{l}\text { Typical properties: - Melting point: } 20^{\circ} \mathrm{C} . \\
\text { Specific gravity: } 1.26 \text {. } \\
\text { Viscosity: } 20-400 \mathrm{mPa} \text {. } \\
\text { Functional category: It's stabilizing agent; suspending agent; tablet } \\
\text { and capsule disintegrant; tablet binder; viscosity-increasing agent. }\end{array}$ & 7,8 \\
\hline 3. & Pectin & $\begin{array}{l}\text { Yellowish } \\
\text { white, odorless } \\
\text { powder. }\end{array}$ & $\begin{array}{l}\text { It is soluble in } \\
\text { water. }\end{array}$ & $6-7.2$ & $\begin{array}{l}\text { Maximum } \\
10\end{array}$ & $\begin{array}{l}30,000- \\
1000,000\end{array}$ & $\begin{array}{l}\text { Pectin is partially soluble in cold } \\
\text { water. It is insoluble in organic } \\
\text { solvents and alcohol. }\end{array}$ & $\begin{array}{l}\text { Pectin is free-flowing, fine powder, and is a stable material. Aqueous } \\
\text { solutions are over a wide } \mathrm{pH} \text { range (pH 3-12) and temperatures } \\
\text { between } 60^{\circ} \mathrm{C} \text {. } \\
\text { Typical properties: } \\
\text { Acidity/alkalinity } \mathrm{pH}: 3.2-4.5 \\
\text { Melting point: } 270^{\circ} \mathrm{C} \\
\text { The heat of combustion: } 14.6 \mathrm{Jg} \\
\text { Specific gravity: } 1.600 \text { at } 25^{\circ} \mathrm{C} \\
\text { Viscosity: } 1200-1600 \mathrm{mPa} \text {. } \\
\text { Functional category: Stabilizing agent; gelling agent; thickening } \\
\text { agent. }\end{array}$ & $\begin{array}{c}7,8,26 \\
27\end{array}$ \\
\hline 4. & Gelatin & $\begin{array}{l}\text { Amber to faintly } \\
\text { yellow-colored, } \\
\text { vitreous, brittle } \\
\text { solid. }\end{array}$ & $\begin{array}{l}\text { It swells in } \\
\text { water and } \\
\text { softens. It's } \\
\text { soluble in } \\
\text { hot water. }\end{array}$ & $\begin{array}{l}3.8-6.0 \\
\text { (type- } \\
\text { A) } \\
5.0-7.4 \\
\text { (type- } \\
\text { B) }\end{array}$ & $\begin{array}{l}\text { Maximum } \\
10\end{array}$ & $\begin{array}{l}15,000- \\
250,000\end{array}$ & $\begin{array}{l}\text { Practically insoluble in acetone, } \\
\text { chloroform, ethanol (95\%), } \\
\text { ether, and methanol. Soluble in } \\
\text { glycerine, acids, and alkalis, } \\
\text { although strong acids or alkalis } \\
\text { cause precipitation. }\end{array}$ & $\begin{array}{l}\text { The higher the average molecular weight, the better the nature of } \\
\text { the film. Errorl Reference source not found., Errorl Reference source not found., 18. } \\
\text { Functional category: It's a coating agent, film former, gelling agent, } \\
\text { suspending agent, tablet binder, viscosity increasing agent. }\end{array}$ & $7,8,28$ \\
\hline 5. & Maltodextrin & $\begin{array}{l}\text { White powder } \\
\text { or granules. }\end{array}$ & $\begin{array}{l}\text { It swells in } \\
\text { water and } \\
\text { softens. It's }\end{array}$ & $4-7$ & $\begin{array}{l}\text { Maximum } \\
6\end{array}$ & Variable & $\begin{array}{l}\text { It is slightly soluble to insoluble } \\
\text { in anhydrous alcohol. Error! Reference }\end{array}$ & $\begin{array}{l}\text { Maltodextrins are characterized by DE (dextrose equivalent) and } \\
\text { have a DE between } 3 \text { to } 20 .{ }^{1} \text { The higher the DE esteem, the shorter }\end{array}$ & $7,8,29$ \\
\hline
\end{tabular}




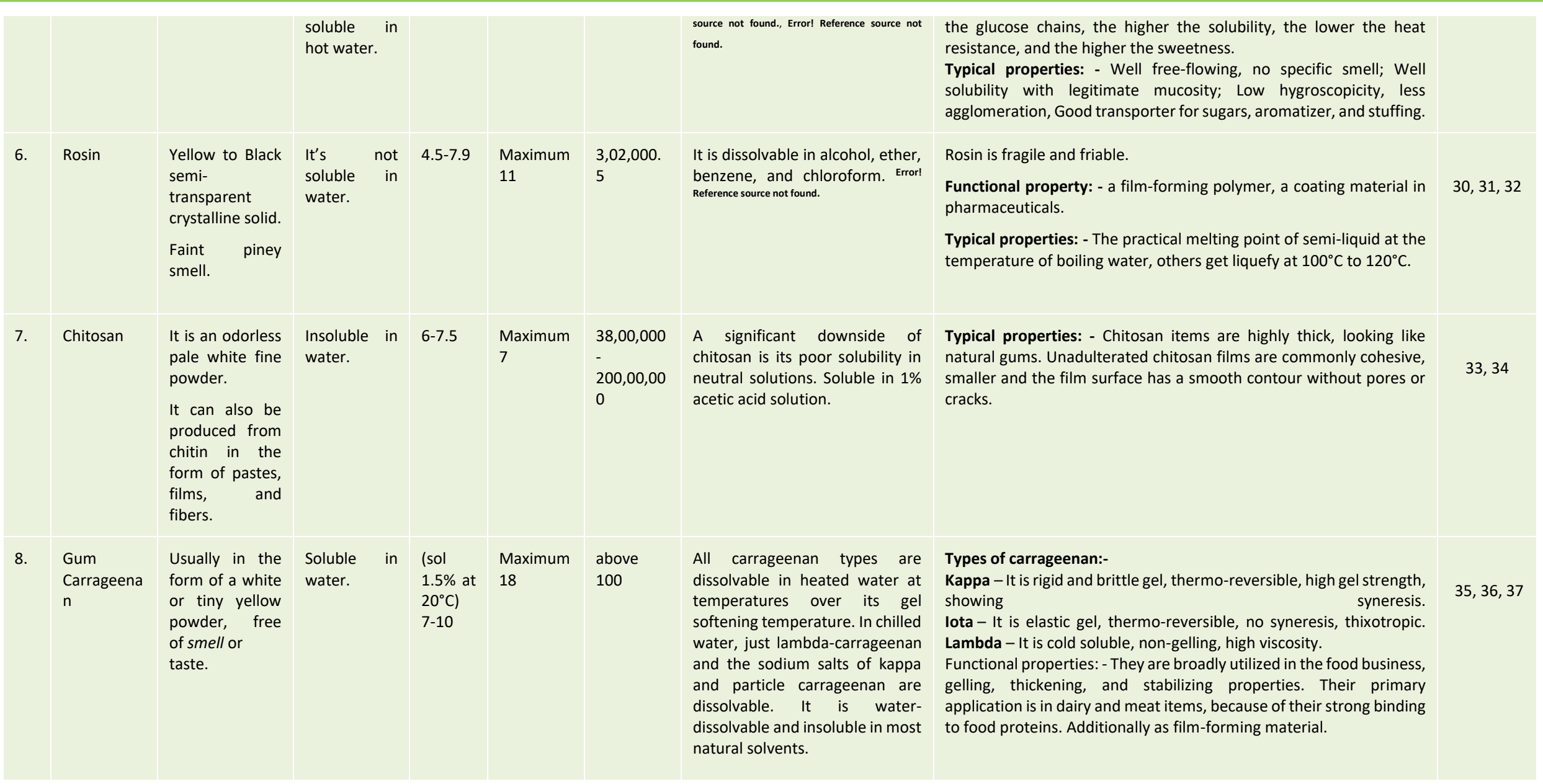


Some Literature review on natural polymers that are utilised for the preparation of mouth dissolving film, they are as shown in Table 3.

Table 3: Literature Review on Natural Polymers Used for some Preparation of MDF ${ }^{7}$

\begin{tabular}{|c|c|c|}
\hline S. No. & Polymer & Drug \\
\hline \multirow[t]{5}{*}{1.} & Pullulan & Cetirizine $\mathrm{HCl}^{38}$ \\
\hline & & Pilocarpine $\mathrm{HCL}$ \\
\hline & & $\begin{array}{l}\text { Propranolol } \\
\text { hydrochloride }\end{array}$ \\
\hline & & Enalapril Maleate ${ }^{4 C}$ \\
\hline & & $\begin{array}{l}\text { Ropinirole } \\
\text { hydrochloride }^{41}\end{array}$ \\
\hline 2. & Starch & Benzocaine \\
\hline
\end{tabular}

Tianeptine Sodium

3. Sodium Medicinal carbon

Alginate

Levocetirizine $\mathrm{HCl}$

Salbutamol Sulfate ${ }^{42}$ Perindopril $^{43}$

4. Gelatin Montelukast sodium ${ }^{44}$

5. Maltodext Piroxicam rin

Nicotine

6. Pectin Propranolol $\mathrm{HCl}^{45}$

\section{Description}

The film shows acceptable thickness, great mechanical properties, great disintegration time, even dispersion and consistency in the film.

A film was easily swell and quickly disintegrate.

The developed formulations demonstrated acceptable outcomes for peel ability, tackiness, weight variation, surface $\mathrm{pH}$, folding endurance, percentage moisture loss, film softening upon storage, percent elongation, disintegration time, transparency, and drug content. Disintegration time of $47 \mathrm{sec}$ and demonstrated promising drug release of $93 \%$ after $20 \mathrm{~min}$.

The pullulan-enalapril maleate blends exhibit good physicochemical properties, as well as a high dissolution rate, which makes these formulations usable as a mucoadhesive buccal film.

There is the fulfillment of all the desirability.

Lycoat RS720 $(25 \% \mathrm{w} / \mathrm{w})$ was utilized to prepare the oral film. This structure offered dose homogeneity with quick dissolution. It permitted hydrophilic, hydrophobic, and also temperature sensitive API's incorporation.

Lycoat NG73 was utilized as a new film-forming agent. Lycoat NG73 indicated most prominent dissolution, acceptable disintegration, and wanted physicomechanical properties.

The addition of sorbitol or mannitol in it caused improvement in the adsorption capacity of therapeutic carbon film when contrasted with its powder structure alongside adequate quality and disintegration time.

Film-forming polymer used was Sodium alginate.

The film was formulated by using Sodium alginate.

Perindopril films were prepared by solvent casting method using sodium alginate at 100,150,200,250,300 mg respectively.

Montelukast sodium fast dissolving film was made by the solvent casting technique with various concentrations of super disintegrants like microcrystalline cellulose and crospovidone utilizing PEG 400 as a plasticizer. It was shown that $4 \%$ crospovidone and $10 \%$ MCC with $4 \%$ gelatin as a film base was reasonable for preparing fast dissolving films of Montelukast sodium.

Maltodextrin with low dextrose comparable as film-forming material was utilized to form an oral film by both casting and an extrusion technique. The homogenous film was acquired by loading a lot of waterinsoluble powders more than $15 \% \mathrm{w} / \mathrm{w}$.

Two distinctive dextrose reciprocals, in particular, DE 6 and DE12 were chosen to assess the impact of polymer molecular weight on film ductile properties. It shows that diminishing the DE estimation of Maltodextrin the tenacity of the film improved.

Fabrication and Evaluation of Fast Disintegrating Oral Hybrid Films of Propranolol Hydrochloride were formulated by using different combination of pectin:HPMC; pectin:PVA; pectin:carbopol; pectin:HPMC E15 LV; with different ratios. But the combination of Pectin:HPMC E15 LV and Pectin:Carbopol results were comparable with that of marketed conventional films of verapamil.

Film formed pectin was found to be optimised amongst other polymers film. The in-vitro drug study was found to give the highest \% diffusion than other formulation. From the in-vitro diffusion studies of fast dissolving films, it was observed that the film showed more \% diffusion at 16 minutes. 
Films from cassava starch had great flexibility and low water permeability, showing potential applications as palatable films. Amylose rich starch is less delicate to aging phenomena than amylopectin rich starch. The changes in elongation are identified with the changes in starch structure and B-type crystallinity. ${ }^{18}$

Lycoat NG 73 is a magnificent film-forming polymer from pea starch. Lycoat is a novel granular hydroxypropyl starch polymer. Lycoat scatters easily in cold water without the development of lumps. ${ }^{7}$ Chemical structure and some quality parameters are as shown in Figure 2 and Table 2.

\section{Maltodextrin:}

Maltodextrin is effectively digestible, being retained as quickly as glucose. Maltodextrin is ordinarily made out of a mixture of chains that differ from three to seventeen glucose units long. ${ }^{12}$ Chemical structure and some quality parameters are as shown in Figure 2 and Table 2.

\section{Chitosan:}

Chitosan ( $\beta$ - $(1,4)$ - 2-amino-2-deoxy-D-glucopyranose), which is chiefly produced using crustacean shells, is the second most abundant natural and non-poisonous polymer in nature after cellulose. ${ }^{23}$ Chemical structure and some quality parameters are as shown in Figure 2 and Table 2.

\section{Gum Carrageenan:}

Carrageenan is a straight chain of partially sulphated galactans.

These sulphated polysaccharides are removed from the cell walls of different red seaweeds (Rhodophyceae). Various seaweeds produce various carrageenans. Recently, carrageenan films were likewise seen as less misty than those made of starch. ${ }^{12,14}$ Chemical structure and some quality parameters are as shown in Figure 2 and Table 2.

\section{REFERENCES}

1. Arora Loveleen, Chakraborty Tanushree, A Review on New Generation Orodispersible Films and its Novel Approaches, Indo American Journal Of Pharmaceutical Research, 7(1), 2017, 7451-7470.

2. Patil Pallavi, Shrivastava S. K., Fast Dissolving Oral Films: An Innovative Drug Delivery System, International Journal of Science and Research (IJSR), 3(7), 2014, 2088-2093.

3. Arya Arun, Chandra Amrish, Sharma Vijay and Pathak Kamla, Fast Dissolving Oral Films: An Innovative Drug Delivery System and Dosage Form, International Journal of Chemtech Research, 2(1), 2010, 576-583.

4. Galgatte Upendra C, Khanchandani Sunil S, Jadhav Yuvraj G, Chaudhari Praveen D, Investigation of Different Polymers, Plasticizers and Superdisintegrating Agents Alone and in Combination for use in the Formulation Of Fast Dissolving Oral Films, International Journal of Pharmtech Research, 5(4), 2013, 1465-1472.

5. Hithun Devaraj, Senthil Venkatachalam and Arun Radhakrishnan; A Review on Formulation of Oral Dissolving Film; Journal of Chemical and Pharmaceutical Research, 10(4), 2018, 151-159.
6. Hassan Mahboob Muhammad Bilal, Riaz Tehseen, Jamshaid Muhammad, Bashir Irfan and Zulfiqar Saqiba, Oral Films: A Comprehensive Review, International Current Pharmaceutical Journal, 5(12), 2016, 111-117.

7. Nagar Priyanka, Chauhan Iti, Yasir Mohd, Insights into Polymers: Film Formers in Mouth Dissolving Films, Drug Invention Today, 3(12), 2011, 280-289.

8. Bala Rajni, Pawar Pravin, Khanna Sushil, Arora Sandeep, Orally Dissolving Strips: A New Approach to Oral Drug Delivery System, International Journal of Pharmaceutical Investigation, 3(2), 2013, 67-76.

9. Hanif Muhammad, Zaman Muhammad \& Chaurasiya Vesh, Polymers used in Buccal Film: A Review, Designed Monomers and Polymers, 18(2), 2015, 105-111.

10. Bhattarai Mukem, Gupta Amit Kumar, Fast Dissolving Oral Films: A Novel Trend to Oral Drug Delivery System, Sunsari Technical College Journal, 2(1), 2015, pg.58-68.

11. Sheoran Reena, Fast Dissolving Oral Films: A Review with Future Prospects, International Journal of Pharmacy \& Pharmaceutical Research, 12(2), 2018, 15-32.

12. Pathare Yogyata S., Hastak Vishakha S., Bajaj Amruta N., Polymers used for Fast Disintegrating Oral Films: A Review, International Journal of Pharmaceutical Sciences Review and Research, 21(1), 2013, 169-178.

13. Muhammad Irfan, Rabel Sumeira, Bukhtar Quratulain, Qadir Muhammad Imran, Farhat Jabeen, Khan Ahmed, Orally Disintegrating Films: A Modern Expansion in Drug Delivery System, Saudi Pharmaceutical Journal 2015.

14. Kulkarni Vishakha S, Butte Kishor D and Rathod Sudha S.; Natural Polymers - A Comprehensive Review, International Journal of Research in Pharmaceutical and Biomedical Sciences, 3(4), 2012, 1597-1613.

15. Halake Kantappa S., Birajdar Mallinath Shrimanth and Kim Byoung Soo; Recently Developed Applications for Natural Hydrophilic Polymers, Journal of Industrial and Engineering Chemistry 40, 2016, 16-22.

16. Arvamudhan Aja, Ramos Daisy M., Nada Ahmed A., Kumbar Sangamesh G., Chapter 4 - Natural Polymers: Polysaccharides and Their Derivatives for Biomedical Applications, Natural and Synthetic Biomedical Polymers 2014, 67-89.

17. M. Bassas-Galia, S. Follonier, M. Pusnik, M. Zinn, 2 - Natural Polymers: A Source of Inspiration, Bioresorbable Polymers for Biomedical Applications, 2017, 31-64.

18. Kaushik Kusum, Sharma Ram Babu, Agarwal Shweta, Natural Polymers and Their Applications, International Journal of Pharmaceutical Sciences Review and Research, 37(2), 2016, 30-36.

19. M Mamatha, B Deepthi, R Sasidhar, Review on Natural Excipients in the Formulation of Oral Fast Dissolving Films, Research and Reviews: Journal of Pharmacology and Toxicological Studies, 4(2), 2016, 148-153.

20. Oğuzhan Pınar and Yangılar Filiz, Pullulan: Production and Usage in Food Industry, African Journal of Food Science and Technology, 4(3), 2013, 57-63.

21. Szekalska Marta, Pucibowska Agata, Szymanska Emilia, Ciosek Patrycja and Winnicka Katarzyna, Alginate: Current Use and Future Perspectives in Pharmaceutical and 
Biomedical Applications, International Journal of Polymer Science, 2016, 1-17.

22. Magallanes-Cruz Perla A., Flores-Silva Pamela C. and BelloPerez Luis A., Starch Structure Influences its Digestibility: A Review, Journal of Food Science, 82(9), 2017, 2016-2023.

23. Chi Fai Cheung Randy, Bun Tzi Ng, Wong Jack Ho and Chan Wai Yee, Chitosan: An Update on Potential Biomedical and Pharmaceutical Applications, Marine Drugs, 13, 2015, 51565186.

24. Leduy Anh, Choplin Lionel, Zajic James E., Luong John H. T., Pullulan Properties, Systhesis and Applications, Wiley's Online Library, 15 April 2014.

25. Prajapati Vipul D., Jani Girish K., Khanda Simin M., Pullulan: An Exopolysaccharide and Its Various Applications, Carbohydrate Polymers, 95(1), 2013, 540-549.

26. Kaur Gaganjot, Grewal Jasleen, Jyoti Kiran, Jain Upendra K., Chandra Ramesh, Madan Jitendra, Chapter 15- Oral Controlled and Sustained Drug Delivery Systems: Concepts, Advances, Preclinical, And Clinical Status, Drug Targeting and Stimuli Sensitive Drug Delivery Systems, 2018, 567-626.

27. Mudgil Deepak, Chapter 3- The Interaction between Insoluble and Soluble Fiber, Dietary Fiber for the Prevention of Cardiovascular Disease, 2017, 35-59.

28. Liu Dasong, Nikoo Mehdi, Boran Gokhan, Zhou Peng and Regenstein Joe M., Collagen and Gelatin, Annual Review of Food Science and Technology, 6, 2015, 527-557.

29. Hofman Denise L., Van Buul Vincent J. and Brouns Fred J. P. H., Nutrition, Health, and Regulatory Aspects of Digestible Maltodextrins, Critical Reviews in Food Science and Nutrition, 56, 2016, 2091-2100.

30. Gundidza M., Mmbengw V., Sibambo1 S.R., Magwa M.L., Mushisha O., Benhura M.A., Gundidza E. and Samie A., Rheological, moisture and ash content analyses of a gum resin from Commiphora Africana, African Journal of Food Science, 5(4), 2011, $188-193$.

31. www.chemicalland21.com, Gum Rosin.

32. PubChem, National Library of medicine, National Center for Biotechnology Information, Gum rosin.

33. Lizardi-Mendoza Jaime, Arguelles Monal Waldo M., Goycoolea Valencia Francisco M., Chapter 1- Chemical Charectristics and Functional Properties of Chitosan, Chitosan In The Preservation Of Agricultural Commodities, 2016, 3-31.

34. Zivanovic S., Davis R.H., Golden D.A., Chapter 8- Chitosan as an antimicrobial in Food Products, Handbook of Natural Antimicrobials for Food Safety and Quality, 2015, 153-181.
35. Demirci Zeynep Ozben, Yılmaz Ismail \& Demirci Ahmet Şukru, Effects of Xanthan, Guar, Carrageenan and Locust Bean Gum Addition on Physical, Chemical and Sensory Properties of Meatballs, Journal of Food Science Technology, 51(5), 2014, 936-942.

36. Sudha Prasad N.; Gomathi Thandapani, Vinodhini P. Angelin, Nasreen K., Chapter 7- Marine Charbohydrates Of Wastewater Treatment, Advances in Food and Nutrition Research, 73, 2014, 103-143.

37. Bemiller James N., 13- Carrageenans, Carbohydrate Chemistry for Food Scientists, Third Edition, 2019, 279-291.

38. Mishra R. and Amin A., Formulation and Characterization of Rapidly Dissolving Films of Cetrizine hydrochloride using Pullulan as a Film Forming Agent, J Pharm Edu Res, 45 (1), 2011, 71-77.

39. Joshua Julie Mariam, Hari R, Jyothish Fithal K, Surendran Saritha A, Formulation of Propranolol Hydrochloride Oral thin films for Migraine Prophylaxis, International Journal of Pharmaceutical Sciences Review and Research, 42(1), 2017, 8-14.

40. Gherman Simona, Zavastin Daniela, Ochiuz Lacramioara, Biliuta Gabriela and Coseri Sergiu, Enalapril Maleate Loaded Pullulan Film for Mucoadhesive Buccal Drug Delivery Applications, Cellulose Chemistry and Technology, 50(5-6), 2016, 593-600.

41. Panchal Mital, Patel Hiren, Bagada Aarti, Vadalia K.R., Formulation and Evaluation of Mouth Dissolving Film of Ropinirole Hydrochloride by using Different Polymers; International Journal of Pharmaceutical Research \& Allied Sciences, 1(3), 2012, 60-72.

42. Prasanthi N.L., Krishna C.S., Gupta M.S., Manikiran S.S., Rao N.R., Design and development of sublingual fast dissolving films for an anti-asthamatic drug, Scholars research library, 3(1), 2011, 382-395.

43. Sundari M.Guna, Dr. Rao M. Gopal, Formulation and Evaluation of Mouth Dissolving Film of Perindopril by Using Natural Polymers, The Tamil Nadu Dr. M.G.R. Medical University Chennai, 2016, 1-100.

44. Ghorwade V., Patil A., Patil S., Ikkurthi K., Sujan Inuganti K., Porandla V., Formulation and evaluation of Montelukast sodium fast dissolving films by using Gelatin as a film base, Research J of Pharm, Bio and Chem Sci, 2(3), 2011, 880-888.

45. AMJ Newton, SM Rani and K Sukhjinder, Fabrication and Evaluation of Fast Disintegrating Oral Hybrid Films of Propranolol Hydrochloride by Using Pectin and Synthetic Polymers, Journal of Developing Drugs, 5(2), 2016, 1-9.

Source of Support: None declared.

Conflict of Interest: None declared.

For any question relates to this article, please reach us at: editor@globalresearchonline.net New manuscripts for publication can be submitted at: submit@globalresearchonline.net and submit_ijpsrr@rediffmail.com 